\title{
STRATEGI PENGEMBANGAN 'KAWAH WURUNG' SEBAGAI TAPAK DESA WISATA DI DESA KALIANYAR KABUPATEN BONDOWOSO
}

\author{
Juhanda \\ Dosen Akademi Pariwisata Muhammadiyah Jember \\ Email: juhanda@akparmuhjember.ac.id
}

\begin{abstract}
ABSTRAK
Strategi pengembangan tapak desa wisata (village tourism site) berbasis masyarakat di Kawah Wurung, yang berlokasi di Dusun Curah Macan, Desa Kalianyar, Kecamatan Sempol-Ijen, Kabupaten Bondowoso, dilakukan dengan menguatkan SDM pariwisata desa (POKDARWIS), penyediaan fasilitas dasar pariwisata, dan menejemen pengelolaannya. Dengan kekhasan dan keunikan alam bekas kawah yang eksotis, dari deretan pegunungan dan kawah Ijen, desa wisata Kawah Wurung mempunyai daya tarik dan pesona yang sangat besar dan kuat bagi calon wisatawan untuk berkunjung. Sampai bulan Mei 2016, jumlah wisatawan yang berkunjung, baik domestik maupun manca negara, terus mengalami grafik peningkatan signifikan, terlebih setelah sejumlah iven-iven wisata digelar secara rutin oleh Pemerintah Kabupaten Bondowoso. Strategi pengembangan tapak desa wisata di Kawah Wurung ini, adalah: 1). Menguatkan potensi tapak wisata Kawah Wurung sebagai desa wisata, untuk selanjutnya dilakukan pembenahan seluruh peta potensi yang dimilikinya sebagai landasan atau acuan pengembangan tapak wisata Kawah Wurung secara utuh di masa mendatang; 2). Mensosialisasikan kepada POKDARWIS dan masyarakat desa tentang potensi kekuatan, kelemahan, peluang dan hambatan/ancaman pada tapak wisata Kawah Wurung, sehingga usaha pengembangan ke depan dapat dilakukan secara benar, menyeluruh dan berkesinambungan sesuai dengan panduan. Dengan demikian, data riil dan analisis lapang atas kebutuhan kebutuhan dasar pariwisata, khususnya untuk desa wisata, penulis jabarkan secara utuh, karena hal itu sebagai prasyarat awal untuk menjadikan tapak wisata desa Kawah Wurung sebagai salah satu icon pariwisata Kabupaten Bondowoso masa depan .
\end{abstract}

Key words: Analisis SWOT, Potensi wisata, Desa wisata, strategi pengembangan. 


\section{PENDAHULUAN}

Pariwisata berbasis masyarakat adalah suatu konsep pengembangan tapak wisata di suatu wilayah perdesaan atau wilayah yang jauh dari perkotaan, yang secara langsung melibatkan dan menyentuh aktifitas penduduk lokal di wilayah tersebut, mulai dari perencanaan, keterlibatan pengembangan, dan kelangsungan pelestariannya, sampai pada kemanfaatannya. Terdapat enam (6) dimensi dari pariwisata yang berbasis pada masyarakat, yaitu: (1) keterlibatan masyarakat; (2) pemberdayaan dan kepemimpinan; (3) menguntungkan masyarakat; (4) kolaborasi dan jejaring; (5) pemasaran dan promosi; dan (6) konservasi (H. Goodwin, R. Santilli : 2008). Bagi tapak wisata perdesaan yang berbasis masyarakat (community-based rural tourism), banyaknya jumlah kunjungan wisatawan yang bercirikan cinta kelestarian alam (nature based) akan sangat positif dan bermanfaat bagi kelangsungan tapak wisata tersebut. Sejalan dengan perkembangan pariwisata berkelanjutan, maka desa wisata (village tourism) merupakan pendekatan pengembangan kepariwisataan yang tepat untuk menjamin agar supaya aktivitas pariwisata dapat dilaksanakan secara aman dan ramah. Dengan demikian, salah satu pendekatan pengembangan wisata alternatif yang ramah lingkungan tersebut adalah desa wisata (village tourism).

Pengembangan tapak wisata berbasis masyarakat di Kawah Wurung, dengan jarak kurang lebih $72 \mathrm{Km}$ dari pusat kota, yang berlokasi di Dusun Curah Macan, Desa Kalianyar, Kecamatan Sempol, Kabupaten Bondowoso, dengan kekhasan dan keunikan bekas kawah dari deretan pegunungan Ijen yang sudah tidak aktif lagi, memang mempunyai daya tarik yang sangat besar bagi calon wisatawan untuk berkunjung. Sampai saat ini jumlah wisatawan yang berkunjung, baik wisatawan domestik maupun asing, terus mengalami peningkatan sejalan dengan iven-iven wisata yang digelar secara rutin oleh pemerintah Kabupaten Bondowoso. Tapak wisata (tourist site) Kawah Wurung sedang diupayakan oleh masyarakat setempat, khususnya yang ada di desa Kalianyar, Dusun Curah Macan, suatu kegiatan penataan tapak di sekitar kawah wurung seadanya, dengan dibantu oleh Dinas Pariwisata Kabupaten Bondowoso.

Selama ini masyarakat di sekitar Kawah Wurung mulai membutuhkan sentuhan konsep pengembangan di berbagai bidang, seperti SDM pariwisata, promosi dan pemasaran, infrastruktur dasar pariwisata, seperti air bersih, penerangan, perbaikan jalan, akomodasi sederhana di rumah rumah penduduk setempat, dan fasilitas fasilitas penting lainnya. Dari sudut pandang kepariwisataan, masyarakat Curah Macan di sekitar Kawah Wurung, masih belum memiliki konsep pemahaman pariwisata yang memadai, bahkan mereka tidak tahu akan dibawa kemana potensi desa wisata yang mereka miliki di masa mendatang. Dengan demikian perlu sekali dilakukan penelitian awal untuk mengetahui kelebihan, kekurangan, peluang, dan hambatan dari tapak desa wisata Kawah Wurung, yang selanjutnya akan bisa dipetakan langkah langkah pengembangannya di masa yang akan datang.

Desa wisata adalah suatu bentuk integrasi antara atraksi, akomodasi dan fasilitas pendukung yang disajikan dalam suatu struktur kehidupan masyarakat yang menyatu dengan tata cara dan tradisi yang berlaku (Nuryanti, 1993). Sedangkan, Inskeep (1995) menyatakan desa wisata merupakan jenis pariwisata dimana sekelompok kecil wisatawan tinggal dalam atau dekat dengan suasana tradisional, sering di desa-desa yang terpencil dan belajar tentang kehidupan pedesaan dan lingkungan setempat.

Tujuan penelitian tentang strategi pengembangan tapak desa wisata (village tourism site) di Kawah Wurung ini adalah: 
1). Menggali potensi desa wisata Kawah Wurung, untuk selanjutnya dilakukan inventarisasi kebutuhan kebutuhan dasar pariwisata di sekitar tapak wisata Kawah Wurung; dan, 2). Mendalami keberadaan pengelolaan organisasi desa wisata Kawah Wurung dalam hal pengelolaan, promosi, dan pelayanan kepada wisatawan. Penelitian ini akan mendalami secara seksama keberadaan potensi desa wisata Kawah Wurung dari sisi temuan kekuatan kekuatan (strengths) yang dimiliki oleh tapak wisata tersebut, yang kemudian akan dilakukan inventarisasi berbagai peluang (opportinities) yang ada, sehingga kemunculan kelemahan kelemahan (weaknesses) dan hambatan hambatan (threaths) yang ada dapat diinventarisasikan secara jelas dan akan dapat ditemukan beberapa pemecahan terhadap persoalan persoalannya.

\section{TINJAUAN PUSTAKA}

\subsection{LandasanTeori}

Kepariwisataan, menurut Organisasi Kepariwisataan Dunia (UNWTO, 2007) adalah serangkaian kegiatan orang atau sekelompok orang yang melakukan perjalanan menuju suatu destinasi wisata dan mereka tinggal sementara di daerah tujuan tersebut, yang lama waktunya tidak lebih dari satu tahun secara berturut-turut, untuk mengisi waktu luang, bisnis, dan tujuan tujuan lainnya, dan mereka tidak bermaksud untuk mencari nafkah di tempat mereka berkunjung. Dalam perkembangannya, sebagaimana yang ditulis oleh Faulker (dalam Gunawan, 2013) bahwa dunia pariwisata telah berkembang pesat, termasuk jenis jenis wisatawan yang melakukan perjalanan wisata. Dengan demikian, tipologi wisatawan modern memiliki sifat sifat antara lain,: (1) jenis wisatawan yang lebih 64ocal64 dan berpengalaman; (2) mereka lebih suka merencanakan perjalanannya sendiri; dan (3) ciri lainnya adalah bersifat spontan, luwes dalam mengatur susunan perjalanan. Kecenderungan mereka lebih tertarik mencari objek wisata dengan jenis minat khusus (special intersest), seperti wisata tirta, petualangan, dan perjalanan mereka biasanya singkat menuju ke satu tujuan wisata saja. Bentuk pariwisata ini apabila dilihat dari tipologi wisatawannya merupakan wisatawan dengan kelompok atau rombongan kecil (Fandeli, 2002). Dari sudut pandang keminatan wisatawan, pariwisata minat khusus ini terfokus pada dua minat, yakni :

a. Minat budaya. Wisatawan jenis ini akan terfokus minat perhatiannya pada bentuk bentuk kesenian, seperti, tarian, musik, kerajinan, pola tradisi masyarakat, aktivitas ekonomi yang spesifik, kearkeologian dan sejarah.

b. Minat Alam. Wisatawan jenis ini lebih terfokus pada minat daya tarik terhadap dunia flora, fauna, geologi, taman nasional, hutan, sungai, danau, pantai, laut dan prilaku ekosistem tertentu.

Pariwisata minat khusus ini juga terkait dengan upaya pengayaan pengalaman atau enriching experience bagi wisatawan yang melaksanakan perjalanan ke daerah-daerah yang masih belum terjamah atau ke daerah yang masih alami. Ada beberapa kriteria yang dapat dipergunakan sebagai pedoman dalam menetapkan suatu bentuk wisata minat khusus (Fandeli, 2002) yakni,

1) Learning, pariwisata yang mendasar pada unsur belajar; 2). Rewarding, pariwisata yang memasukkan unsur pemberian penghargaan; 3). Enriching, pariwisata yang memasukkan peluang terjadinya pengkayaan pengetahuan antara wisatawan dengan masyarakat; dan, 4). Adventuring, pariwisata yang dirancang dan dikemas sehingga terbentuk wisata petualangan.

\subsection{Konsep Desa Wisata}

Pitana (2006: 137) menyatakan bahwa untuk dapat meningkatkan partisipasi masyarakat maka sangat diperlukan program-program pembangunan atau inovasi-inovasi yang dikembangkan mengandung unsur-unsur :

1) Memberikan keuntungan secara relatif, terjangkau secara ekonomi, dan ekonomis 
karena biaya yang dikeluarkan lebih kecil dari hasil yang diperoleh (relative advantage); 2) Unsur-unsur dari inovasi dianggap tidak bertentangan dengan nilainilai dan kepercayaan setempat (compatibility); 3) Gagasan baru dan praktek baru yang dikomunikasikan dapat dengan mudah dipahami dan dijalankan (complexity and practicability); dan, 4) Unsur-unsur inovasi tersebut mudah diobservasi hasilnya lewat demonstrasi atau paraktek peragaan (observability).

Woodly,1993, (dalam Pitana 2006) dengan tegas menyatakan bahwa "local people participation is a prerequisite for sustainable tourism". Jika dikembangkan dalam perspektif pemberdayaan, maka terdapat tiga komponen yang harus ada, yaitu :

1. Enabling setting, yaitu memperkuat situasi kondisi di tingkat lokal menjadi baik, sehingga masyarakat local bisa berkreativitas. Ibaratnya, membuat panggung yang baik, sehingga masyarakat local bisa menari diatas panggung tersebut.

2. Empowering local community. Setelah ada panggung yang baik untuk menari maka masyarakat setempat harus ditingkatkan kemampuannya menari. Artinya, setelah local setting disiapkan, masyarakat lokal harus ditingkatkan pengetahuan dan ketrampilannya, sehingga mampu memanfaatkan setting dengan baik. Hal ini antara lain dilakukan melalui pendidikan, pelatihan dan berbagai bentuk pengembangan SDM lainnya.

3. Socio-political support. Kalau panggung sudah baik, masyarakat lokal sudah bisa menari, maka diperlukan adanya perangkat pendukung lain, seperti perlengkapan, penonton dan seterusnya, yang tidak lain berupa dukungan sosial, dukungan politik, jejaring, dan sebagainya. Tanpa dukungan sosial politik yang memadai, masyarakat lokal tidak akan bisa "menari" dengan baik di "panggung", meskipun masyarakat tersebut sesungguhnya pintar "menari" (Pitana, 2004).

\section{METODE PENELITIAN \\ 3.1 Observasi, Wawancara dan Kuesioner}

Metode observasi adalah pengamatan langsung peneliti di lapang berikut cakupan lingkungan fisiknya dan/atau pengamatan secara langsung suatu kegiatan yang sedang berjalan. Data yang dikumpulkan melalui observasi cenderung mempunyai keandalan yang tinggi. Tidak jarang metode observasi dilakukan untuk mengecek validitas dari data yang telah diperoleh sebelumnya dari individu-individu. Peneliti melihat secara langsung apa yang sedang dikerjakan, pekerjaan-pekerjaan yang rumit kadangkadang sulit untuk diterangkan oleh responden. Metode observasi juga dapat menggambarkan lingkungan fisik dari kegiatan-kegiatan, misalnya tata letak fisik peralatan, penerangan, gangguan suara, dan lain-lain.

Sedangkan metode wawancara merupakan suatu teknik pengumpulan data dengan jalan mengadakan komunikasi dengan sumber data. Komunikasi tersebut dilakukan dengan dialog (tanya jawab) secara lisan, baik langsung maupun tidak langsung (Djumhur dan Surya, 1985).

Daftar pertanyaan (kuesioner) adalah suatu daftar yang berisi pertanyaan pertanyaan untuk tujuan khusus yang memungkinkan seorang peneliti untuk mengumpulkan data dari para responden yang telah dipilih. Daftar pertanyaan ini kemudian akan dikirim kepada para responden yang akan mengisinya sesuai dengan pendapat mereka. Acuan pengisian kuisioner ini adalah sebagai berikut:

\section{Tabel 3.1 Acuan Pengisian Kuesioner}

Penelitian kondisi saat ini:

- Sangat baik dengan skor : 4

- Baik dengan skor: 3

- Cukup dengan skor: 2

Kurang dengan skor: 1 
Dalam penelitian ini, data dan informasi yang akan dikumpulkan oleh peneliti bersifat kualitatif. Ahmad Said (2005: 51) mengemukakan ada lima ciriciri dari sebuah penelitian kualitatif, yaitu: 1). Penelitian kualitatif dilakukan pada latar alamiah (natural setting) sebagai sumber data langsung dan data penelitian ini merupakan instrumen kunci (key instrument); 2). Penelitian ini bersifat deskriptif, yaitu menggambarkan situasi tertentu atau data yang dikumpulkan berbentuk kata-kata dari pada angka-angka; 3). Penelitian ini lebih memperhatikan proses dari pada hasil atau produk semata; 4). Dalam proses menganalisa data cenderung secara induktif ; dan, 5). Makna merupakan hal yang esensial bagi penelitian kualitatif.

Tahapan penelitian akan dilakukan langsung ke lapangan, yaitu di Desa Kalianyar, Kecamatan Sempol, Kabupaten Bondowoso, dengan terlebih dahulu menyiapkan alat alat pengumpul informasi, antara lain: a). Sejumlah lembaran kuesioner dan daftar pertanyaan dalam wawancara; b). Alat alat kelengkapan audio visual, seperti alat perekam suara dan kamera. Informasi awal hasil observasi, wawancara, dan kuesioner, di lapangan akan peneliti olah berdasarkan alat analisis yang dipakai, yaitu analisis SWOT. Pendekatan penelitian ini bersifat partisipatoris dimana peneliti terlibat langsung dalam berpartisipasi dalam rangka mewujudkan tapak wisata Kawah Wurung menjadi desa wisata yang maju di masa yang akan datang.

Indikator indikator yang akan diukur oleh peneliti tentang keberadaan desa wisata Kawah Wurung, antara lain: 1). Kekuatan kekuatan daya tarik tapak wisata Kawah Wurung; 2). Apa saja permasalahan yang membuat tapak wisata Kawah Wurung menjadi lemah; 3). Faktor faktor apa saja yang menjadikan peluang berkembangnya tapak wisata Kawah Wurung; dan 4). Apa saja faktor faktor yang menjadi ancaman/hambatan berkembangnya tapak wisata Kawah Wurung saat ini. Diagram langkah langkah sederhana di bawah ini yang akan menjadi alur penelitian di tapak wisata Kawah Wurung, Desa Kalinyar, Kecamatan Sempol, Bondowoso.

\subsection{Analisis SWOT}

Analisis SWOT (SWOT analysis) di sini mencakup upaya-upaya untuk mengenali kekuatan, kelemahan, peluang, dan ancaman yang menentukan kinerja perusahaan. Informasi eksternal mengeni peluang dan ancaman dapat diperoleh dari banyak sumber, termasuk pelanggan, dokumen pemerintah, pemasok, kalangan perbankan, rekan diperusahaan lain. Banyak perusahaan menggunakan jasa lembaga pemindaian untuk memperoleh keliping surat kabar, riset di internet, dan analisis tren-tren domestik dan global yang relevan ( Richard L. Daft, 2010: 253). Selanjutnya, Fredi Rangkuti (2004: 18) menjelaskan bahwa analisis SWOT adalah identifikasi berbagai faktor secara sistematis untuk merumuskan strategi perusahaan. Analisis ini didasarkan pada logika yang dapat memaksimalkan kekuatan (strengths) dan peluang (opportunities), namun secara bersamaan dapat meminimalkan kelemahan (weaknesses) dan ancaman (threats). Proses pengambilan keputusan strategi selalu berkaitan dengan pengembangan misi, tujuan, strategi dan kebijakan perusahaan.

Dalam konteks pariwisata, perencanaan strategis harus menganalisa faktor faktor strategi keberadaan potensi pariwisata (kekuatan, kelemahan, peluang dan ancaman) pada kondisi yang ada saat ini.

Analisis SWOT membandingkan antara faktor eksternal peluang (opportunities) dan ancaman (threats) dengan faktor internal kekuatan (strenghts) dan kelemahan (weaknesses). Menurut Irham Fahmi (2013: 260), untuk menganalisis secara lebih dalam tentang 
SWOT, maka perlu dilihat faktor eksternal dan internal sebagai bagian penting dalam analisis SWOT tersebut, yaitu pertama faktor eksternal. Faktor eksternal ini mempengaruhi terbentuknya opportunities and threats $(\mathrm{O}$ dan $\mathrm{T})$, dimana faktor ini meliputi kondisi-kondisi yang terjadi di luar keberadaan pariwisata yang mempengaruhi dalam pembuatan keputusan dan kebijakan pariwisata. Faktor ini mencakup lingkungan industri dan lingkungan bisnis makro, ekonomi, politik, hukum, teknologi, kependudukan, dan sosial budaya. Kedua, faktor internal. Faktor internal ini mempengaruhi terbentuknya strenghts and weaknesses (S dan W), dimana faktor ini menyangkut kondisi yang terjadi dalam pariwisata itu sendiri, yang mana ini turut mempengaruhi terbentuknya pembuatan keputusan (decision making) dan kebijakan tentang pariwisata. Faktor internal ini meliputi semua jenis manajemen fungsional: pemasaran, keuangan, operasi, sumberdaya manusia, penelitian dan pengembangan, sistem informasi manajemen dan perilaku budaya masyarakat (local culture behavior).

Model analisis SWOT membandingkan antara faktor eksternal peluang dan ancaman dengan faktor internal kekuatan dan kelemahan. Faktor internal dimasukan ke dalam matrik yang disebut matrik faktor strategi internal atau IFAS (Internal Strategic Factor Analisis Summary). Faktor eksternal dimasukkan ke dalam matrik yang disebut matrik faktor strategi eksternal EFAS (External Strategic Factor Analisis Summary). Setelah matrik faktor strategi internal dan eksternal selesai disusun, kemudian hasilnya dimasukkan dalam model kuantitatif, yaitu matrik SWOT, untuk merumuskan strategi kompetitif tapak wisata.

Tabel 3.3 Matrik Faktor Strategi Eksternal (EFAS)

\begin{tabular}{|l|c|c|c|l|}
\hline $\begin{array}{c}\text { Faktor } \\
\text { Strategi } \\
\text { Eksternal }\end{array}$ & Bobot & Rating & $\begin{array}{c}\text { Bobot } \\
\mathbf{X} \\
\text { Rating }\end{array}$ & Keterangan \\
\hline Peluang & $\mathbf{X}$ & $\mathbf{X}$ & $\mathbf{X}$ & \\
\hline Jumlah & $\mathbf{X}$ & $\mathbf{X}$ & $\mathbf{X}$ & \\
\hline Ancaman & $\mathbf{X}$ & $\mathbf{X}$ & $\mathbf{X}$ & \\
\hline Jumlah & $\mathbf{X}$ & $\mathbf{X}$ & $\mathbf{X}$ & \\
\hline Total & $\mathbf{X}$ & $\mathbf{X}$ & $\mathbf{X}$ & \\
\hline
\end{tabular}

Sumber: Rangkuti, $2004: 18$

Tabel 3.4 Matrik Faktor Strategi Internal (IFAS)

\begin{tabular}{|l|c|c|c|c|}
\hline $\begin{array}{c}\text { Faktor } \\
\text { Strategi } \\
\text { Internal }\end{array}$ & Bobot & Rating & $\begin{array}{c}\text { Bobot } \\
\mathbf{X} \\
\text { Rating }\end{array}$ & Keterangan \\
\hline Kekuatan & $\mathbf{X}$ & $\mathbf{X}$ & $\mathbf{X}$ & \\
\hline Jumlah & $\mathbf{X}$ & $\mathbf{X}$ & $\mathbf{X}$ & \\
\hline Kelemahan & $\mathbf{X}$ & $\mathbf{X}$ & $\mathbf{X}$ & \\
\hline Jumlah & $\mathbf{X}$ & $\mathbf{X}$ & $\mathbf{X}$ & \\
\hline Total & $\mathbf{X}$ & $\mathbf{X}$ & $\mathbf{X}$ & \\
\hline
\end{tabular}

\section{Sumber:Rangkuti,2004:}

Alat yang dipakai untuk menyusun faktor-faktor strategis tapak wisata Kawah Wurung adalah matrik SWOT. Matrik ini dapat mengambarkan secara jelas bagaimana peluang dan ancaman eksternal yang dihadapi Kawah Wurung dapat disesuaikan dengan kekuatan dan kelemahan yang dimilikinya. Matrik ini dapat menghasilkan 4 set kemungkinan alternatif strategis.

Tabel 3.5 Diagram Matrik SWOT

\begin{tabular}{|c|c|c|}
\hline IFAS & STRENGTHS & WEAKNESSES \\
EFAS & $\begin{array}{c}\text { (S) } \\
\text { Tentukan 5-10 faktor } \\
\text { kekuatan internal }\end{array}$ & $\begin{array}{c}\text { Tentukan 5-10 faktor } \\
\text { kelemahan internal }\end{array}$ \\
\hline
\end{tabular}




\begin{tabular}{|c|c|c|}
\hline $\begin{array}{c}\text { OPPORTUNITIES } \\
\text { (O) Tentukan 5-10 } \\
\text { faktor peluang } \\
\text { eksternal }\end{array}$ & $\begin{array}{c}\text { STRATEGI } \\
\text { (SO) } \\
\text { Ciptakan strategi yang } \\
\text { menggunakan kekuatan } \\
\text { untuk memanfaatkan } \\
\text { peluang }\end{array}$ & $\begin{array}{c}\text { STRATEGI } \\
\text { (WO) } \\
\text { Ciptakan strategi yang } \\
\text { meminimalkan kelemahan } \\
\text { untuk memanfaatkan } \\
\text { peluang }\end{array}$ \\
\hline $\begin{array}{c}\text { THREATS } \\
\text { Tentukan 5-10 } \\
\text { faktor }\end{array}$ & $\begin{array}{c}\text { STRATEGI } \\
\text { (ST) }\end{array}$ & $\begin{array}{c}\text { STRATEGI } \\
\text { (WT) }\end{array}$ \\
eksternal & $\begin{array}{c}\text { Ciptakan strategi yang } \\
\text { menggunakan kekuatan } \\
\text { untuk mengatasi } \\
\text { ancaman/hambatan }\end{array}$ & $\begin{array}{c}\text { Ciptakan strategi yang } \\
\text { meminimalkan kelemahan } \\
\text { untuk menghindari } \\
\text { ancaman/hambatan }\end{array}$ \\
\hline
\end{tabular}

\section{Sumber: Rangkuti, 2004: 18}

Strategi SO (Strength-Opportunities) ini dibuat berdasarkan realitas tapak wisata Kawah Wurung, yaitu dengan memanfaatkan seluruh kekuatan potensi Kawah Wurung untuk merebut dan memanfaatkan peluang yang sebesarbesarnya. Strategi ST (Strenghts-Threats) adalah strategi dalam menggunakan kekuatan yang dimiliki tapak wisata Kawah Wurung untuk mengatasi ancaman/hambatan. Strategi WO (Weknesses-Opportunities) diterapkan berdasarkan pemanfaatan peluang yang ada di Kawah Wurung dengan cara meminimalkan kelemahan yang ada.
Sedangkan, strategi WT (WeknessesThreats) berdasarkan pada kegiatan yang bersifat defensif dan berusaha meminimalkan kelemahan yang ada serta menghindari ancaman/hambatan hambatan yang ada. Dari rona awal (existing condition) yang terdapat di tapak wisata Kawah Wurung saat ini, serta semakin dikenalnya Kawah Wurung di berbagai kota di Indonesia akibat dari digelarnya banyak event wisata dan perbaikan perbaikan fasilitas dasar wisata di lokasi Kawah Wurung, maka perkembangan Kawah Wurung di masa depan akan semakin

\begin{tabular}{|c|c|c|}
\hline No & Variabel & Indikator \\
\hline \multirow{7}{*}{1.} & \multirow{7}{*}{ Atraksi Wisata } & - Keindahan alam perkebunan kopi Arabica \\
\hline & & - Keindahan view kawah wurung dengan savananya \\
\hline & & - Terdapat pemandian air sungai yang hangat \\
\hline & & - Beragamnya hasil pertanian: kentang, wortel, kubis, dll. \\
\hline & & - Kawasan yang dekat dengan kawah Ijen \\
\hline & & - Iklim pegunungan yang bersih dan sejuk \\
\hline & & - Kebun kopi Arabica milik masyarakat berkualitas dunia. \\
\hline \multirow{3}{*}{2} & \multirow{3}{*}{ Jarak Tempuh } & $\begin{array}{l}\text { - jalur wisatanya satu jalan dengan tapak wisata Gunung Ijen } \\
\text { dan tapak wisata Kawah Wurung }\end{array}$ \\
\hline & & - akses jalan menuju Kawah Wurung standar eko wisata \\
\hline & & $\begin{array}{l}\text { - berdekatan jarak antar } 3 \text { tapak wisata unggulan, Kawah } \\
\text { Ijen, Kawah Wurung, dan Air Terjun Sempol. }\end{array}$ \\
\hline \multirow{3}{*}{3} & \multirow{3}{*}{$\begin{array}{l}\text { Besaran } \\
\text { Desa }\end{array}$} & $\begin{array}{l}\text { - Desa Kalianyar memiliki wilayah yang cukup luas, yaitu } \\
40,28 \mathrm{Km} 2\end{array}$ \\
\hline & & - SDM yang memadai, yaitu 3.362 orang \\
\hline & & $\begin{array}{l}\text { - densitas penduduk yang ideal dan sebagian besar berlokasi } \\
\text { di perkebunan kopi PTPN dan kebun rakyat. }\end{array}$ \\
\hline
\end{tabular}




\begin{tabular}{|c|c|c|}
\hline 4 & Kondisi Keagamaan & $\begin{array}{l}\text { - masyarakat desa Kalianyar mayoritas beragama Islam yang } \\
\text { toleran } \\
\text { - Masyarakat masih berperilaku budaya gotong royong } \\
\text { secara solid }\end{array}$ \\
\hline 5 & $\begin{array}{l}\text { Ketersediaan } \\
\text { Infrastruktur }\end{array}$ & $\begin{array}{l}\text { - tersedia rumah rumah masyarakat sebagai sarana } \\
\text { penginapan bagi wisatawan } \\
\text { - fasilitas air bersih dan MCK memadai } \\
\text { - jumlah warung masyarakat tersedia secara memadai } \\
\text { - tersediannya pemandu lokal dari Pokdarwis desa Kalianyar } \\
\text { - tersedianya jalur ke beberapa tapak wisata terdekat, } \\
\text { khususnya Kawah Ijen dan Air Terjun Sempol. } \\
\text { - fasilitas penerangan tersedia dan memadai }\end{array}$ \\
\hline
\end{tabular}

\subsection{Identifikasi Variabel}

Sesuai dengan model penelitian yang dirancang, ada beberapa variabel yang diidentifikasikan. Dalam evaluasi variabel eksternal yang diidentifikasi meliputi lingkungan jauh. Variabel lingkungan jauh antara lain: lingkungan politik, ekonomi, sosial dan teknologi (PEST). Dalam evaluasi internal ada beberapa variabel yang diidentifikasi dan dianalisis lebih lanjut adalah variabel-variabel yang menyangkut kriteria Desa Wisata yang meliputi: Atraksi wisata, jarak tempuh, besaran desa, kepercayaan masyarakat dan Kemasyarakatan, dan ketersediaan infrastruktur terkait dengan potensi Desa wisata Kawah Wurung untuk dikembangkan sebagai Desa Wisata berbasis masyarakat.

\begin{tabular}{|c|c|c|}
\hline Nilai & Range & Hasil \\
\hline 4 & $3,26 \cdot 4,00$ & Sangat Baik \\
\hline 3 & $2,51 \cdot 3,25$ & Baik \\
\hline 2 & $1,76 \cdot 2,50$ & Kurang Baik \\
\hline 1 & $1,00 \cdot 1,75$ & Sangat Kurang Baik \\
\hline
\end{tabular}

Sumber: Rudika, 2004:77.

Berdasarkan Tabel 3.8 variabel eksternal memberikan gambaran tentang peluang dan ancaman. Apabila nilai yang diperoleh dengan sebutan baik dan sangat baik, maka akan merupakan suatu peluang bagi perusahaan, tetapi apabila nilai yang diperoleh dengan sebutan kurang baik dan sangat kurang baik maka hal tersebut merupakan suatu ancaman. Berdasarkan tabel 3.8 posisi peluang berada pada rentang nilai 2,51 sampai 4,00 dan posisi ancaman berada pada rentang nilai 1,00 sampai dengan 2,50. Sementara, lingkungan internal, memberikan gambaran tentang kekuatan dan kelemahan organisasi. Sebutan sangat baik diidentikkan dengan sangat kuat, baik diidentikkan dengan kuat, kurang baik diidentikan dengan lemah, sangat kurang baik diidentikan dengan sangat lemah. Jadi Kreteria baik dan sangat baik merupakan kekuatan, berada pada rentang nilai 2,51 sampai dengan 4,00 sedangkan kurang baik dan sangat kurang baik merupakan kelemahan berada pada rentang nilai 1,00 sampai dengan 2,50.

\section{HASIL DAN PEMBAHASAN 4.1 Gambaran Umum Kecamatan Sempol (Kecamatan Baru. Ijen)}

Kecamatan Sempol merupakan salah satu kecamatan dari 23 kecamatan yang ada di Kabupaten Bondowoso dengan jarak lebih kurang $60 \mathrm{~km}$ arah timur dari ibukota kabupaten. Secara geografis Kecamatan Sempol terletak pada ketinggian $1.050 \mathrm{~s} / \mathrm{d}$ 1.500 meter di atas permukaan laut. Wilayah Kecamatan Sempol sebelah utara 
berbatasan dengan Kecamatan Arjasa Kabupaten Situbondo dan Di sebelah barat berbatasan dengan Kecamatan Kec. Cermee, Kec. Sumberwringin dan Kecamatan Tlogosari, sebelah Timur berbatasan dengan Kecamatan Glagah Kabupaten Banyuwangi, sedangkan sebelah selatan berbatasan dengan Kecamatan Temuguruh Kabupaten Banyuwangi. Luas wilayah Kecamatan Sempol mencapai 217,20 Km2 yang terbagi menjadi 6 Desa, 34 Dusun, 32 Rukun Warga dan 81 Rukun Tetangga. Jumlah penduduk hasil proyeksi Tahun 2014 sebanyak 11.789 Jiwa ( Statistik Daerah Kecamatan Sempol, 2015). Kecamatan Sempol memiliki luas wilayah 217,20 Km2 terbagi menjadi 6 desa, 38 Dusun, $38 \mathrm{Rw}$ dan 84 Rt. Dilihat pada tabel disamping Desa Kalianyar mempunyai jumlah Dusun, Rw, dan Rt terbanyak, yaitu 9 Dusun, 9 Rw dan 21 Rt.

\section{Tabel: 4.2 Wilayah Administrasi}

\section{Kecamatan Ijen (Sempol)}

\begin{tabular}{|cccccc|}
\hline No & Desa & $\begin{array}{c}\text { Luas } \\
\text { Wil. } \\
\left(\mathrm{km}^{2}\right)\end{array}$ & Dusun & $\begin{array}{c}\text { Rukun } \\
\text { warga }\end{array}$ & $\begin{array}{c}\text { Rukun } \\
\text { Tetangga }\end{array}$ \\
\hline 1 & Sempo1 & 15,96 & 5 & 5 & 12 \\
\hline 2 & Kalianyar & 40,28 & 9 & 9 & 21 \\
\hline 3 & Kalisat & 9,16 & 6 & 6 & 17 \\
\hline 4 & Jampit & 71,24 & 6 & 6 & 11 \\
\hline 5 & $\begin{array}{l}\text { Sumber } \\
\text { rejo }\end{array}$ & 30,31 & 6 & 6 & 15 \\
\hline 6 & \begin{tabular}{l} 
Kaligedang \\
\hline
\end{tabular} & 50,25 & 6 & 6 & 8 \\
\hline
\end{tabular}

Sumber: Statistik Kec. Sempol, 2015

Desa Kalianyar, dari jumlah penduduk dan densitasnya memiliki jumlah terbesar dibandingkan dengan desa desa lainnya di Kecamatan Ijen, masing masing 3.362 penduduk dengan kepadatan (densitas) penduduknya 106, 94. Tabel di bawah ini menunjukkan posisi penting desa Kalianyar dari segi sumber daya manausia, termasuk di dalamnya SDM pariwisata. Di desa Kalianyar, Dusun Curah Macan, terdapat organisasi desa wisata, yaitu Kelompok Sadar Wisata (POKDARWIS) Kawah Wurung, yang terdiri dari anak anak muda desa, laiki dan perempuan, dengan bimbingan dari Dinas Pariwisata Daerah Bondowoso, dimana peneliti adalah salah seorang naras umber dan pendorong berdirinya Pokdarwis tersebut.

Tabel: 4.3 Luas Wilayah, Jumlah dan

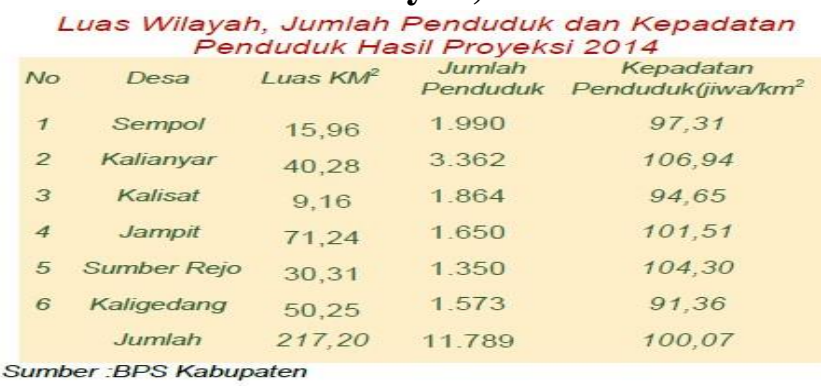

\section{Tabel: 4.4 Tabel Kunjungan Wisman \& Wisnus di Tapak Wisata Sempol}

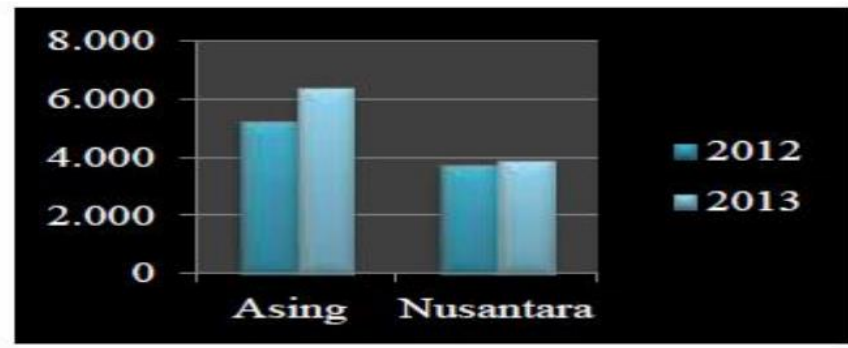

Sumber: Dinas Pariwisata, 2014

Desa Kalianyar, Dusun Curah Macan, adalah lokasi tapak wisata Kawah Wurung yang belum lama dikelola oleh pemerintah Kabupaten Bondowoso bersama masyarakat lokal, namun sangat pesat perkembangannya karena memiliki keunikan dan kekhasan tapak wisatanya, yaitu sebuah kawah gunung berapi yang tidak jadi dan tidak aktif, dengan topografi yang eksotis. Dari table data di atas menunjukkan bahwa tingkat kunjungan wisatawan dari manca negara menduduki posisi tertinggi pada tahun 2012 dan 2013 secara berturut-turut. Hal tersebut mengindikasikan bahwa minat kunjungan wisatawan asing, khususnya dari Belanda dan Jepang, berikutnya Amerika dan Australia, sangat tertarik pada wisata alam perdesaan yang masih orisinil dan wisata perkebunan. Saat ini Desa Kalianyar merupakan pemasok kopi rakyat jenis Arabica berkualitas ekspor di Kecamatan Ijen (dahulu Sempol) khususnya, dan di Kabupaten Bondowoso pada umumnya. beberapa tahun lalu Kabupaten Bondowoso 
mendeklarasikan daerahnya sebagai Republik Kopi.

Kawah Wurung, sebuah tapak wisata alam dengan jarak kurang lebih $72 \mathrm{Km}$ dari pusat kota, yang berlokasi di Dusun Curah Macan, Desa Kalianyar, Kecamatan Sempol, Kabupaten Bondowoso, memiliki kekhasan dan keunikan sebuah bekas kawah dari deretan pegunungan Ijen yang sudah tidak aktif lagi. Sampai saat ini jumlah wisatawan yang berkunjung, baik wisatawan domestik maupun asing, terus mengalami peningkatan sejalan dengan iven-iven wisata yang digelar secara rutin oleh pemerintah Kabupaten Bondowoso. Tapak wisata (tourist site) Kawah Wurung sedang diupayakan oleh masyarakat setempat, khususnya yang ada di desa Kalianyar, Dusun Curah Macan, suatu kegiatan penataan tapak di sekitar kawah wurung seadanya, dengan dibantu oleh Dinas Pariwisata Kabupaten Bondowoso.

\subsection{Analisis dan Skor Lingkungan Internal}

Untuk menilai lingkungan internal potensi kawasan Desa Wisata Kawah Wurung digunakan pedoman identifikasi dan definisi variabel seperti disajikan dalam Tabel 4.1 Pemeringkatan diberikan dengan menjawab pilihan dari empat alternatif yaitu sangat buruk, buruk, baik dan sangat baik. Hasil penelitian menunjukkan masing-masing responden memberikan nilai yang bervariasi. Perhitungan nilai peringkat (rating) responden didasarkan pada nilai rata-rata dari seluruh responden. Pemeringkatan yang diberikan oleh responden terlihat pada table

4.1 .

Tabel 4.1 Peringkatan/Rating Lingkungan Internal (Internal Factors Analysis Summary)

\begin{tabular}{|c|l|c|}
\hline \multirow{2}{*}{ No } & \multicolumn{1}{|c|}{ Faktor Internal (Internal Factors) } & Rating \\
\cline { 2 - 3 } & \multicolumn{1}{|c|}{ Kekuatan (Strengths) } & \multicolumn{1}{|c|}{\begin{tabular}{c}
\multicolumn{1}{|c|}{} \\
unik
\end{tabular}} \\
\hline 2. & Adanya dua tapak wisata yang berdekatan, Kawah ljen dan Air Terjun Sempol & 3,837 \\
\hline 3. & Adanya produk kopi khas produksi Masyarakat Kalianyar dan PTPN XII & 3,876 \\
\hline 4. & $\begin{array}{l}\text { Adanya Padang gembala terbuka sapi \& hasil pertanian kentang, kubis \& } \\
\text { strawberry }\end{array}$ & 3,755 \\
\hline 5. & $\begin{array}{l}\text { Kesenian penduduk lokal: mocopatan madura, dan musik seremonial } \\
\text { keagamaan }\end{array}$ & 3,704 \\
\hline 6. & $\begin{array}{l}\text { Situs peninggalan zaman kolonial Belanda berupa sarana akomodasi a la } \\
\text { Belanda }\end{array}$ & 3,753 \\
\hline 7. & Adanya fasilitas olahraga minat khusus, yakni Paralayang dan gantole & 3,892 \\
\hline 8. & Adanya event olahraga bermotor off-road dengan moto-trail \& mountain bike & 3,821 \\
\hline 9. & $\begin{array}{l}\text { Melimpahnya produk pertanian lainnya:buah avocado, wortel, ketela khusus } \\
\text { tape, dll. }\end{array}$ & 3.331 \\
\hline No & \multicolumn{1}{|c|}{ Kelemahan (weaknesses) } & Rating \\
\hline 1 & $\begin{array}{l}\text { Kondisi jalan aspal desa rusak berlobang, jalan makadam \& tanah yang tidak } \\
\text { nyaman }\end{array}$ & 2,832 \\
\hline 2 & $\begin{array}{l}\text { Pengelolaan fasilitas dasar: parkir, MCK, listrik, rumah makan, dll belum } \\
\text { standar }\end{array}$ & 2,791 \\
\hline 3 & $\begin{array}{l}\text { Kebijakan harga, antara lain: tiket tidak berbasis IT \& single ticket, bahasa } \\
\text { pengantar }\end{array}$ & 2.775 \\
\hline 4 & Sumber daya manusia yang kompeten mengelola tapak wisata Kawah Wurung & 2.471 \\
\hline
\end{tabular}

Sumber: Hasil Analisis, 2016 


\subsection{Analisis dan Skor Lingkungan Eksternal.}

Lingkungan eksternal dari kawasan Desa wisata Kalianyar sebagai desa Wisata berbasis masyarakat yang akan menciptakan peluang dan ancaman dinilai oleh 45 orang responden yang terdiri dari para stakeholder pariwisata yang terdiri dari unsur pemerintah, tokoh masyarakat, pengusaha pariwisata, wisatawan, dan pihak akademisi yang ada di Kawasan Desa Kalianyar. Dalam menilai lingkungan eksternal, responden memakai pedoman identifikasi faktor lingkungan eksternal yang sudah disiapkan. Hasil penelitian juga menunjukkan adanya variasi nilai yang diberikan responden terhadap masingmasing indikator. Untuk mendapatkan nilai dari semua responden maka dihitung berdasarkan rata-rata (mean) persepsi responden. Adapun hasil penelitian terhadap pemeringkatan responden terhadap lingkungan eksternal dapat dilihat pada kolom rating pada Tabel 4.2.

Tabel 4.2 Peringkat/Rating Lingk. Eksternal (External Factor Analysis Summary)

\begin{tabular}{|c|c|c|}
\hline \multirow[t]{2}{*}{ No. } & $\begin{array}{c}\text { Peringkat/Rating Lingkungan Eksternal (External Factor Analysis } \\
\text { Summary) }\end{array}$ & \multirow[t]{2}{*}{ Rating } \\
\hline & Peluang (Opportinities) & \\
\hline 1 & $\begin{array}{l}\text { Liburan Natal \& Tahun Baru (foreign tourists) dengan kebijakan } \\
\text { pemerintah free visa kunjungan kepada } 169 \text { negara asing }\end{array}$ & 3.957 \\
\hline 2 & $\begin{array}{l}\text { Kesan Kawah Ijen yang sudah go international terhadap tapak wiata } \\
\text { Kawah Wurung yang eksotis, tipikal, naturally unique. }\end{array}$ & 3.778 \\
\hline 3 & Stabilitas ekonomi makro Indonesia \& daya beli masyarakat meningkat & 3.655 \\
\hline 4 & $\begin{array}{l}\text { Meningkatnya kebutuhan seseorang dan keluarga untuk berlibur saat ini } \\
\text { cukup tinggi }\end{array}$ & 3.882 \\
\hline 5 & $\begin{array}{l}\text { Faktor keamanan di Indonesia terjamin dan keindahan wisata alam } \\
\text { (natural attraction) secara makro untuk berlibur sangat tinggi }\end{array}$ & 3.887 \\
\hline 6 & $\begin{array}{l}\text { Kesan ummat Islam Indonesia sebagai mayoritas mulai berubah menjadi } \\
\text { kesan sejuk, damai, dan aman (Faktor Sapta Pesona Pariwisata) }\end{array}$ & 3.654 \\
\hline 7 & $\begin{array}{l}\text { Dijalinnya kerjasama } G \text { to } G \text { dengan Saudi Arabia merupakan citra baru } \\
\text { dunia internasional terhadap Indonesia. }\end{array}$ & 3.777 \\
\hline No & Ancaman/Hambatan (threats) & Rating \\
\hline 1 & $\begin{array}{l}\text { Munculnya competitor lain yang kelas dan jenis daya tarik wisatanya } \\
\text { sama atau serupa (comparative \& competitive advantages) }\end{array}$ & 2.443 \\
\hline 2 & $\begin{array}{l}\text { Diberlakukanya travel warning bagi wisatawan manca negara untuk } \\
\text { berkunjung ke Indonesia karena faktor keamanan, dll. }\end{array}$ & 2.655 \\
\hline 3 & $\begin{array}{l}\text { Terjadinya distabilitas perekonomian nasional \& } \\
\text { pengangguran }\end{array}$ & 2.622 \\
\hline
\end{tabular}

Sumber: Hasil Analisis, 2016

\subsection{Strategi Pengembangan Desa Wisata Kawah Wurung Berbasis Masyarakat}

Untuk mengembangkan Desa Kalianyar sebagai Desa Wisata berbasis masyarakat (rural-base tourism development) di Kecamatan Ijen (nama baru-sebelumnya Kecamatan Sempol) di Kabupaten Bondowoso yang berkelanjutan serta menguntungkan semua pihak dan tetap melestarikan alam perlu dirumuskan strategi dalam pengembangannya. Berdasarkan hasil kajian kekuatan dan kelemahan dari faktor internal serta peluang dan ancaman dari faktor eksternal, maka dengan analisis SWOT akan ditemukan strategi dan program 


\section{Tabel 4.3 Strategi Pengembangan Desa Wisata Kawah Wurung di Desa Kalianyar}

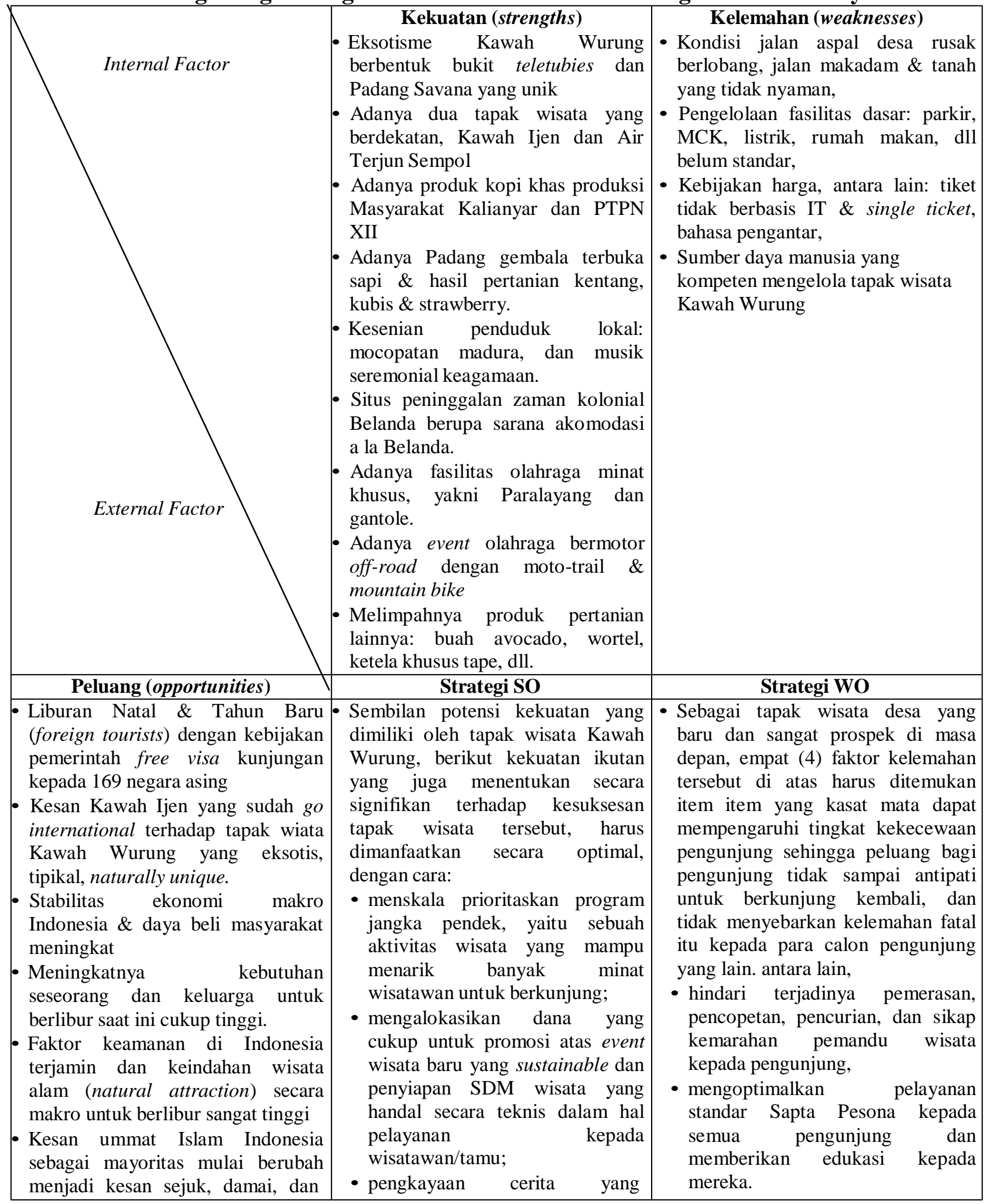




\begin{tabular}{|c|c|c|}
\hline $\begin{array}{l}\text { aman (Faktor Sapta Pesona } \\
\text { Pariwisata) } \\
\text { - Dijalinnya kerjasama } G \text { to } G \\
\text { dengan Saudi Arabia merupakan } \\
\text { citra baru dunia internasional } \\
\text { terhadap Indonesia. }\end{array}$ & $\begin{array}{l}\text { membuat pengunjung penasaran; } \\
\text { dan, } \\
\text { - berikan atensi khusus pada } \\
\text { wisatawan khusus (special guest) } \\
\text { serta remaja \& pemuda (generasi } \\
\text { Millenial) }\end{array}$ & $\begin{array}{lr}\text { - hadiahi pengunjung } & \text { khusus } \\
\text { (special } & \text { guest) } \\
\text { cinderamata } & \begin{array}{r}\text { dengan } \\
\text { khas }\end{array} \\
\text { Bondowoso/Kawah Wurung. }\end{array}$ \\
\hline Ancaman (threats) & Strategi ST & Strategi WT \\
\hline \begin{tabular}{|l} 
- Munculnya competitor lain yang \\
kelas dan jenis daya tarik \\
wisatanya sama atau serupa \\
(comparative \& competitive \\
advantages), \\
- Diberlakukanya travel warning \\
bagi wisatawan manca negara \\
untuk berkunjung ke Indonesia \\
karena faktor keamanan, dll. \\
- Terjadinya distabilitas \\
perekonomian nasional \& \\
banyaknya pengangguran.
\end{tabular} & $\begin{array}{l}\text { Kekuatan tapak desa Wisata baru } \\
\text { Kawah Wurung, yang berdekatan } \\
\text { jarak dengan tapak wisata Kawah } \\
\text { Ijen dan Air terjun Sempol adalah } \\
\text { kekuatan pengikat sekaligus } \\
\text { perekat bagi wisatawan untuk } \\
\text { tinggal lebih lama (length of stay) } \\
\text { di Kecamatan Ijen. strateginya } \\
\text { antara lain: } \\
\text { - ciptakan segitiga emas (triangle } \\
\text { gold) "Ijen Blue Fire-Kawah } \\
\text { Wurung-Sempol Waterfalls" } \\
\text { bagi wisatawan special tour } \\
\text { package untuk mendapatkan } \\
\text { kepuasan optimal; } \\
\text { - hindari atau minimalkan } \\
\text { kebosanan untuk terus bergerak, } \\
\text { selalu tawarkan bantuan, jaga } \\
\text { keselamatan, dan hindari } \\
\text { pemerasan kepada wisatawan; } \\
\text { - berikan sertifikasi, berupa } \\
\text { sertifikat diri atas capaian } \\
\text { prestasi menjelajah gold triangle } \\
\text { pada wisatawan sebagai kenang- } \\
\text { kenangan. }\end{array}$ & $\begin{array}{l}\text { - Strategi meminimalkan kelemahan } \\
\text { internal di desa wisata Kawah } \\
\text { Wurung harus diberorientasi penuh } \\
\text { kepada pengelolaan wisatawan } \\
\text { (tourist focus oriented } \\
\text { management); } \\
\text { - Mengoptimalkan } \\
\text { pelatihan teknis berbagai item } \\
\text { gelaran (event) secara kreatif- } \\
\text { inovatif berjadwal dan profesional; } \\
\text { Strategi di atas dapat dilakukan } \\
\text { secara kolektif dengan model FGD } \\
\text { (Focus Group Discussion), antara } \\
\text { lain: } \\
\text { - ciptakan kisah kisah magis pada } \\
\text { tapak tapak wisata di desa } \\
\text { Kalianyar dalam bentuk buku } \\
\text { saku bergambar menarik, } \\
\text { termasuk cerita rekaan (folklore) } \\
\text { yang masuk akal (logis) kepada } \\
\text { wisatawan. } \\
\text { - pepatah mengatakan 'padamkan } \\
\text { api dengan air'. dalam hal ini, } \\
\text { para pesaing (competitors) kita } \\
\text { dari luar selalu ingin } \\
\text { merendahkan atau menomor } \\
\text { duakan tapak wisata desa kita. } \\
\text { hadapilah seperti air yang } \\
\text { menyejukkan sembari terus } \\
\text { berbenah diri terus menerus. }\end{array}$ \\
\hline
\end{tabular}

Data diolah, 2017

Berdasarkan analisis SWOT yang disajikan dalam Tabel 4.3 disusun strategi pengembangan Desa Wisata Kawah Wurung berbasis masyarakat di desa Kalianyar. Adapun beberapa alternatif strategi yang dapat dirumuskan dalam mengembangkan Desa Wisata berbasis masyarakat di desa Kalianyar adalah sebagai berikut :

1. Strategi Strengths-Opportunities (SO). Strategi ini berupaya untuk memanfaatkan kekuatan yang dimiliki untuk meraih peluang-peluang yang ada dari luar atau dari lingkungan eksternal. Strategi yang dapat diterapkan dalam mengembangkan Desa Wisata Kawah Wurung berbasis masyarakat di desa Kalianyar adalah memilih dan mengembangkan skala prioritas pertama dalam item kekuatan daya Tarik wisata desa di Kawah Wurung yang dipasangkan dengan peluang paling besar terhadap pasar wisatawan secara berkualitas dan berkelanjutan.

2. Strategi Strengths-Threats (ST). Strategi ini memanfaatkan kekuatan untuk menghadapi ancaman. Strategi yang dapat dilakukan dalam mengembangkan Desa Wisata Kawah Wurung berbasis 
masyarakat di desa Kalianyar adalah meningkatan promosi melalui penggunaan kemajuan teknologi informasi. Ciptakan program segitiga emas (gold triangle) "Ijen Blue FireKawah Wurung-Sempol Waterfalls" bagi wisatawan dalam special tour package untuk mendapatkan kepuasan optimal; dan berikan sertifikasi, berupa sertifikat diri atas capaian prestasi menjelajah gold triangle pada wisatawan sebagai kenang-kenangan.

3. Strategi Weaknesses-Threats (WO). Dalam kuadran ini, strategi yang dirancang adalah berusaha meminimalkan kelemahan dengan berusaha memanfaatkan peluang yang ada. Strategi pengembangan yang dapat diterapkan di Desa wisata Kawah Wurung Kalianyar ini adalah strategi peningkatan SDM pariwisata secara berkualitas dan berkelanjutan. mengoptimalkan pelayanan standar Sapta Pesona kepada semua pengunjung dan memberikan edukasi kepada mereka. Menghadiahi pengunjung khusus (special guest) dengan cinderamata khas Bondowoso/Kawah Wurung.

4. Strategi Weaknesses-Threats (WT). Strategi ini bertujuan untuk bertahan dengan meminimalisir kelemahan dengan menghindari ancaman. Strategi yang dapat diterapkan dalam mengembangkan Desa Wisata Kawah Wurung berbasis masyarakat di desa Kalianyar ini adalah Strategi meminimalkan kelemahan internal di desa wisata Kawah Wurung dengan tetap berorientasi penuh kepada pengelolaan wisatawan (tourist focus oriented management);

Mengoptimalkan pelatihan pelatihan teknis berbagai item gelaran (event) secara kreatif-inovatif berjadwal dan profesional; Strategi di atas dapat dilakukan secara kolektif dengan model FGD (Focus Group Discussion), yang antara lain: a. Berkreasi menciptakan kisah kisah magis pada tapak tapak wisata di desa Kalianyar dalam bentuk buku saku bergambar menarik, termasuk cerita rekaan (folklore) yang masuk akal (logis); merangkai pantun pantun humor dalam bentuk buku saku, dan funny puzzle (tebak-tebakan lucu) kepada wisatawan.

b. Pepatah mengatakan 'padamkan api dengan air'. Dalam kontek ini, para pesaing (competitors) kita dari luar daerah ingin merendahkan atau menomor duakan tapak wisata desa yang kita miliki. Oleh karena itu hadapilah mereka di lapangan seperti air yang segar menyejukkan, sembari terus berbenah diri secara profesional dan berkelanjutan.

\section{SIMPULAN DAN SARAN}

\subsection{Simpulan}

Dari analisis yang dilakukan terhadap lingkungan internal dan eksternal tapak Desa Wisata Kawah Wurung di desa Kalianyar sebagai daya tarik wisata berbasis masyarakat dapat disimpulkan sebagai berikut :

1. Faktor-faktor internal yang menjadi kekuatan dari tapak Desa Wisata Kawah Wurung di desa Kalianyar antara lain:

a. Eksotisme Kawah Wurung berbentuk bukit teletubies dan Padang Savana yang unik.

b. Adanya dua tapak wisata yang berdekatan, Kawah Ijen dan Air Terjun Sempol

c. Adanya produk kopi khas produksi Masyarakat Kalianyar dan PTPN XII

d. Adanya Padang gembala terbuka sapi \& hasil pertanian kentang, kubis \& strawberry.

e. Kesenian penduduk lokal: mocopatan madura, dan musik seremonial keagamaan.

f. Situs peninggalan zaman kolonial Belanda berupa sarana akomodasi a la

Belanda. 
g. Adanya fasilitas olahraga minat khusus, yakni Paralayang dan gantole.

h. Adanya event olahraga bermotor off-road dengan moto-trail \& mountain bike

i. Melimpahnya produk pertanian lainnya: buah avocado, wortel, ketela khusus tape, dll..

2. Faktor-faktor yang menjadi peluang berkembangnya tapak Desa Wisata Kawah Wurung di desa Kalianyar, antara lain:

a. Liburan Natal \& Tahun Baru (foreign tourists) dengan kebijakan pemerintah free visa kunjungan kepada 169 negara manca;

b. Kesan Kawah Ijen yang sudah go international terhadap tapak wiata Kawah Wurung yang eksotis, tipikal, naturally unique;

c. Stabilitas ekonomi makro Indonesia \& daya beli masyarakat meningkat;

d. Meningkatnya kebutuhan seseorang dan keluarga untuk berlibur saat ini cukup tinggi;

e. Faktor keamanan di Indonesia terjamin dan keindahan wisata alam (natural attraction) secara makro untuk berlibur sangat tinggi;

f. Kesan ummat Islam Indonesia sebagai mayoritas mulai berubah menjadi kesan sejuk, damai, dan aman (Faktor Sapta Pesona Pariwisata); dan,

g. Dijalinnya kerjasama $G$ to $G$ dengan Saudi Arabia merupakan citra baru dunia internasional terhadap Indonesia.

3. Berdasarkan analisis Matrik InternalEkternal (IE), posisi Kawasan tapak Desa Wisata Kawah Wurung di desa Kalianyar sebagai daya tarik ekowisata alam adalah ada pada quadran I, artinya pengembangan Kawasan tapak Desa Wisata Kawah Wurung di desa Kalianyar sebagai Daya Tarik wisata alam perdesaan harus menerapkan taktik grow and build strategy, yaitu strategi penetrasi pasar, strategi pengembangan pasar, dan strategi pengembangan produk. Sedangkan strategi alternatif lain yang dapat dikembangkan adalah mengkreasi dan pengembangan produk wisata alam perdesaan yang bersifat package tour kolektif yang bernuansa edukasi; strategi peningkatan promosi melalui penggunaan kemajuan teknologi informasi, strategi pembuatan paket wisata. Sembilan potensi kekuatan yang dimiliki oleh tapak wisata Kawah Wurung, berikut kekuatan ikutan yang juga menentukan secara signifikan terhadap kesuksesan tapak wisata tersebut, harus dimanfaatkan secara optimal, dengan cara:

a. menskala prioritaskan program jangka pendek, yaitu sebuah aktivitas wisata yang mampu menarik banyak minat wisatawan untuk berkunjung;

b. mengalokasikan dana yang cukup untuk promosi atas event wisata baru yang sustainable dan penyiapan SDM wisata yang handal secara teknis dalam hal pelayanan kepada wisatawan/tamu;

c. pengkayaan cerita yang membuat pengunjung penasaran; dan,

d. berikan atensi khusus pada wisatawan khusus (special guest) serta remaja \& pemuda (generasi Millenial)

4. Strategi alternatif yang ditetapkan di atas dapat dijabarkan dengan beberapa program yaitu:

a. Pelathan teknis yang berkelanjutan terhadap ibu ibu rumah tangga perdesaan tentang pelayanan prima berbasis tourist-base oriented service, yaitu tumpuan pelayanan yang utama adalah pelayanan kepada wisatawan atau tamu, khususnya dalam hal kuliner dan cindera mata.

b. Strategi meminimalkan kelemahan internal di desa wisata Kawah Wurung harus diberorientasi penuh kepada pengelolaan minat dan kepentingan wisatawan (tourist focus oriented management);

c. Mengoptimalkan pelatihan pelatihan teknis berbagai item gelaran (event) 
secara kreatif-inovatif berjadwal dan profesional;

d. Strategi di atas dapat dilakukan secara kolektif dengan model FGD (Focus Group Discussion), antara lain:

- ciptakan kisah kisah magis pada tapak tapak wisata di desa Kalianyar dalam bentuk buku saku bergambar menarik, termasuk cerita rekaan (folklore) yang masuk akal (logis) kepada wisatawan.

- pepatah mengatakan 'padamkan api dengan air'. dalam hal ini, para pesaing (competitors) kita dari luar selalu ingin merendahkan atau menomor duakan tapak wisata desa kita. hadapilah seperti air yang menyejukkan sembari terus berbenah diri terus menerus.

\subsection{Saran}

Berdasarkan kelemahan dan ancaman yang dimiliki oleh Kawasan tapak Desa Wisata Kawah Wurung di desa Kalianyar sebagai daya tarik wisata alam sehingga dalam pengembangannya tetap melestarikan lingkungan, meningkatkan kualitas pengalaman wisatawan, memberikan manfaat bagi penduduk lokal secara berkelanjutan, maka dapat disarankan beberapa hal antara lain :

1. Masyarakat lokal di kawasan tapak Wisata Kawah Wurung di desa Kalianyar, dengan Kelompok Sadar Wisatanya (POKDARWIS), harus mengambil peran sebagai stakeholder utama, yakni sebagai kaum 'Anshor' (di zaman Rasululloh SAW) selalu minta dibina dan dilatih oleh personalia Dinas Pariwisata Kabupaten agar supaya meningkat standar kompetensinya di bidang pariwisata dalam menerapkan Sapta Pesona.

2. POKDARWIS desa wisata Kawah Wurung, dengan berdiskusi bersama Dinas Pariwisata Daerah untuk merencanakan membuat package tour dengan tawaran "Triangle Gold: "Ijen Blue Fire-Kawah Wurung-Sempol Waterfalls". Terobosan terobosan paket unik bersertifikat ini (Highly Certified Experience of Bondowoso Triangle Gold) akan membuat desa wisata Kawah Wurung selalu menjadi Update bagi wisatawan.

\section{DAFTAR PUSTAKA}

Fandeli, C. (2002). Perencanaan Kepariwisataan Alam. . Fakultas Kehutanan Universitas Gadjah Mada, Bulaksumur, Yogyakarta.

Gunawan, Imam.2013. Metode Penelitian Kualitatif: Teori \& Praktik. Penerbit: Bumi Aksara Inskeep,1995. Tourism Planning An Integrated and Sustainable Development Approach

Kusmayadi dan Sugiarto. 2002. Metodelogi Penelitian di Bidang Kepariwisataan. Jakarta: PT Gramedia Pustaka Utama.

Nasir.1988. Metode Penelitian. Ghalia Indonesia Jakarta.

Nuryanti, Wiendu. 1993. Concept,

Perspective and Challenges, makalah bagian dari Laporan

Pitana, I Gde 2004. Mispersepsi Pemberdayaan Masyarakat dalam Kepariwisaaan Bali. Bali Post, Maret 2004. Hal 7

Pitana, I Gde dan Gayatri Putu G. 2005. Sosiologi Pariwisata. Yogyakarta: Andi Offset.

Pitana, I Gde. 2006. Kepariwisataan Bali Dalam Wacana Otonomi Daerah. Jakarta: Puslitbang kepariwisataan.

Putra, 2008. Eksotisme Sebagai Modal Dasar Pengembangan Desa Wisata. Diunduh dari http://tourism.padang.go.id/index.php ?tourism $=$ news\&id $=5$

Rangkuti, Freddy. 2004. Analisis SWOT Teknik Membedah Kasus Bisnis. Jakarta: PT

Gramedia Pustaka Utama.

Santilli R. 2008. "Community-Based Tourism: an Assessment of the Factors for Success". University of Greenwich unpublished 


\section{Jurnal Sadar Wisata}

Volume 1, No 1, Juni 2017, Hal 62-78

Umar, H. 2003. Strategic Management in Action. Jakarta: PT.Gramedia Pustaka Utama.

Wainhill,. Stephen 1993. Tourism Principle and Practice. London : Pitman Publishing.

World Tourism Organization (UNWTO). 2007. A Practical Guide to Tourism Destination Management. Published and printed by the, Madrid, Spain. ISBN: 978-92-844-1243-3 . First printing, All rights reserved 